\title{
Determination of the factors affecting sexual violence against women in Turkey: a population-based analysis
}

\author{
Ömer Alkan ${ }^{*}$ (1) and Hasan Hüseyin Tekmanlı(D)
}

\begin{abstract}
Background: Sexual violence is one of the most investigated types of violence by national and international decision makers. The purpose of this study was to detect the factors that affect sexual violence against women in Turkey.

Methods: In this study, a cross-sectional data set was employed from the survey titled the National Research on Domestic Violence against Women in Turkey, which was conducted by the Hacettepe University Institute of Population Studies. Binary logistic and probit regression analyses were used to determine the factors influential in women's exposure to sexual violence.

Results: The findings obtained from the analyses indicated that women's exposure to sexual violence was influenced by a variety of factors including region, age, level of education, employment status, health condition, marital status, number of children as well as exposure to physical, economic, and verbal abuse. In addition, it was determined that the level of education, employment status, drug use, infidelity and other variables related to the husband/partner of the women who participated in the survey affected the women's exposure to sexual violence.

Conclusion: There remains a higher probability of exposure to sexual violence among women residing in rural and less developed regions. A decrease in the women's level of education increased their probability of exposure to sexual violence. An increase in the women's age and an increase in the level of education of the women's husbands/partners lowered the probability of their exposure to sexual violence. There was a higher probability of exposure to sexual violence among women who had experienced physical, economic, and verbal abuse.
\end{abstract}

Keywords: Domestic violence, Intimate partner violence, Sexual violence, Violence against women, Turkey

\section{Background}

Notwithstanding that it is a concept that changes according to time and socio-cultural structure, violence has become one of the most prominent issues in recent years [43]. Acts of violence are behavioral patterns that are internalized in the socialization process by new generations and passed down to other generations in this manner $[5,9]$. One of the most common forms of violence

*Correspondence: oalkan@atauni.edu.tr

Department of Econometrics, Faculty of Economics and Administrative Sciences, Ataturk University, Erzurum, Turkey against women is domestic violence committed by a husband or partner. Intimate partner violence (IPV), which is often referred to as domestic violence, takes various forms [55]. The intimate partner in such cases of violence is the husband/partner with whom the woman has sexual intercourse with or the father of the child she carried in her womb [38]. In the literature, non-physical violence is categorized into four different types emotional violence, psychological violence, social violence and economic violence $[6,53]$. Physical and sexual violence refers to the form of violence regarding physical intervention against women $[21,38]$. 
Violence is defined as the exertion of physical force upon another person from which there is a strong possibility that murder, injury, psychological damage or other negative changes will result. Furthermore, it is the use of physical force against oneself, another person or a group that deliberately causes or is likely to cause injury, death, psychological harm, negative development and/or deprivation. Violence can be physical, sexual or psychological in nature and can also include acts of deprivation or negligence [37]. There is no doubt that sexual violence is one of the most dangerous types of violence. Women all around the world face the risk of physical or sexual abuse by an intimate partner or another offender [35]. Sexual violence and IPV can lead to physical injuries, deterioration in mental health, and specific chronic physical ailments. In some cases such types of violence can even result in disability or death for some victims [18].

Sexual violence is a type of domestic violence that mostly occurs in marriage or intimate partnership scenarios [29]. Sexual violence and IPV are usually addressed together. In such cases, the concept of sexual violence by the intimate partner emerges and is very difficult to understand and measure as it includes both sexual violence and IPV [54]. While the most common manifestation of this form of violence is rape or sexual assault, women can also experience complicated situations such as coercion for sexual abuse or pornography, threats and blackmail [13].

Sexual violence takes place in all societies around the world, albeit under different definitions [33]. Sexual violence is defined as physically forcing another person to have sexual intercourse without their consent, having sexual intercourse because of the fear of the partner, and/ or being forced to perform a sexual act deemed humiliating [56].

Although sexual violence concerns both genders, women are more likely to be victims and in most cases the perpetrators are male and known by the victim. Moreover, children are particularly vulnerable to sexual abuse and girls are especially at greater danger at school [20]. Victims of sexual violence experience physical, social, mental, emotional, and sexual problems. Because of its severe psychological and sociological impact on the victim, sexual violence further escalates feelings of helplessness and weakness that can drain the victim's self-esteem and fuel a sense of vulnerability in the face of subsequent sexual violence [33]. From a more general classification, sexual violence results in the deterioration of mental and reproductive health and in the emergence of behavioral, social, and fatal consequences for the victim [17]. In addition, the expected results include hostility and blame on the basis of fear and anxiety in the short term and sleep disorders, depression, anxiety, obsession, acute stress disorder, mental retardation, and various significant health problems in the long term [46]. Sexual violence and forced sexual intercourse cause a range of gynecological and reproductive health problems such as HIV and other sexually transmitted infections, unwanted pregnancy, vaginal bleeding or infection, myoma, decreased sexual desire, genital irritation, pain during sexual intercourse, chronic pelvic pain and urinary tract infections [44]. Furthermore, they can causes short-term problems such as shock, fear, anxiety, panic, phobias, guilt, sleep disorders, eating disorders, and long-term psychological problems such as anxiety disorder, panic disorder, depression and suicide attempts [32]. Moreover, in extramarital affairs, some of the other potential outcomes are the failure of victims to form adult relationships, devalued expectations from marriage, and rejection by family and friends. In certain cultures there is even a possibility of beating or murdering the victim to protect the family honor [17].

On an international level, 30\% of women experience some form of physical or sexual violence by their intimate partner during their lifetime. In cases of femicide, $38 \%$ to $50 \%$ of these acts are committed by the intimate partner. A vast majority of victims (55\% to $95 \%$ ) choose not to report the violence or take action to protect their rights [57], which is why it is difficult to obtain statistical records of sexual violence. The risk of facing sexual violence among women between the ages of 16 and 19 is four times higher than for other age groups and three times higher among women between the ages of 18 and 24. South Africa ranks at the top of the global list of countries with the highest rates of sexual violence or rape (132.4 incidents per 100 people) and is followed by, in descending the order, Botswana, Lesotho, Eswatini (Swaziland), Bermuda, Sweden, Surinam, Costa Rica, Nicaragua, and Grenada. With 1.5 incident per one hundred thousand people, Turkey is among the lowest ranking countries on this list [48].

In Turkey, the laws regarding women's rights and violence against women are noticeably modernized. However, most women have no idea of their rights, which may be due to the cultural norm that men own women, manhood is all about violence, and violence is just ordinary behavior. In addition, as Turkish people commonly adhere to Islamic norms, which order women to be submissive to men, it is generally accepted that rebelling against one's husband is a sin [36]. As per the traditions and religious norms in Turkey, it is believed that violence, sexuality, and similar domestic matters should not be intervened with. As women widely hold the belief that, in marriage, the sexual needs of men must be met, they do not consider acts of sexual violence as criminal acts and 
never speak openly about these acts anywhere, let alone to judicial authorities [29].

The Regulation on the Implementation of the Law on the Protection of the Family enacted in 2008 regulated the measures to be taken against family members committing violence and the procedures and principles regarding the implementation of these measures. On combating violence against women, The Council of Europe Convention on Preventing and Combating Violence against Women and Domestic Violence, also known as the Istanbul Convention, was opened for signature in 2011 and came into force on 8 March 2012. This convention is one step ahead than former conventions in terms of the extended definition of violence against women and protecting and supporting women subjected to violence without considering stalking and cohabitation. With the Istanbul Convention, steps were taken to regulate the provisions of Law No. 4320 to prevent violence only in marriage. In order to eliminate the flaws in the implementation of this law, on March 8, 2012 Law No. 6284 on the Protection of the Family and the Prevention of Violence against Women entered into force. Law No. 6284 aims to protect women, children and victims of unilateral stalking who are married, engaged, divorced, in a relationship or who ended a relationship and are exposed to violence or in danger of being exposed to violence. By means of this particular law, the scope of the protective measure decisions aimed at preventing violence against individuals exposed to violence were extended and measures such as changing the identity information of the individuals concerned were included. Moreover, in order to be able to take preventive cautionary decisions against individuals who commit violence, the powers of the law enforcement officers in addition to judges were restructured in cases where delays were inconvenient [23]. The aim of these regulations is to prevent violence against women.

In a study conducted in Ankara, Turkey with 1178 women via a questionnaire, $31.3 \%$ of the respondents claimed to have experienced sexual violence from their husbands at least once, while $25.8 \%$ of the respondents claimed to have been physically forced to engage in sexual intercourse. Moreover, it was revealed that compared to the previous year, the ratio of exposure to sexual violence had increased by $15.9 \%$ [2]. In a study conducted in Turkey with 12,795 women via a questionnaire, $15 \%$ of married women between the ages of 15 and 49 reported to have experienced sexual or physical violence by their husband or intimate partner within the last 12 months. In another study carried out in Edirne, Turkey, it was determined that the rate of exposure to sexual violence was $6.3 \%$. According to the findings of the study, the decrease in social support and the breakdown of marital relationship increased sexual violence [42]. In a study conducted on domestic violence including physical, verbal, economic, psychological and sexual violence in Eskişehir, Turkey, it was determined that the prevalence of sexual violence was $6.9 \%$. [26]. In a study carried out in Isparta, Turkey, verbal/psychological, physical, emotional, economic and sexual violence were addressed within the scope of domestic violence and the rate of the exposure to sexual violence by husbands was determined as $38 \%$ [30]. In a study conducted in Konya, Turkey, it was found that approximately $38 \%$ of women were exposed to sexual violence [3].

Violence against women has long been a research topic in the scientific world and has been investigated in various aspects. In Turkey, the statistical methods or cross-sectional data sets for sexual violence are relatively insufficient compared to other types of violence. The present study aimed to fill this void in the literature by analyzing sexual violence via more specific variables in addition to cross-sectional data sets and demographic variables. In line with this purpose, the factors that influence sexual violence against women were modeled for Turkey via a rich data set.

\section{Methods \\ Study design}

The National Research on Domestic Violence against Women in Turkey is one of the most comprehensive studies conducted nationwide in order to understand the dimension, content, causes and effects and risk factors of domestic violence experienced by women in Turkey. It was conducted for the first time in 2008 in order to determine the different aspects and reasons of violence against women and to meet the requirement of collecting data on this issue. The National Research on Domestic Violence against Women in Turkey conducted in 2014 is significant in terms of reflecting the change regarding violence against women since the research conducted in 2008 [22, 23].

The research questionnaire was designed by taking into account the questionnaire applied by the WHO in the study titled "Multi-country Study on Women's Health and Domestic Violence against Women" [25]. New questions regarding country specific requirements, particularly targeting the monitoring of legal regulations, were also added to the questionnaire $[22,23]$.

\section{Setting}

Within the scope of research on violence Turkey has been divided into 30 strata in order to ensure obtaining estimates at country level, urban/ rural level, at 12 and 5 regions level. Except for the Istanbul region, which is among one of the 12 regions, the distribution regarding 
urban and rural strata were at a rate of approximately $75 \%$ to $25 \%$ in the other regions. In Istanbul, approximately $5 \%$ of the households were selected from the rural areas. In the research, settlements with a population of 10.000 and above constituted the urban strata, and those with a population less than 10.000 constituted the rural strata. The sampling of the research was carried out using cluster sampling [22, 23].

The field study of the research conducted in 2008 started on 27 July 2008 and was completed on 29 September 2008 [22]. The field study of the research conducted in 2014 started on 8 April 2014 and was completed on 11 July 2014 [23].

\section{Participants}

The National Research on Domestic Violence against Women in Turkey was conducted among women between the ages of 15 and 59 . Women who were married, currently in a relationship, or had previously been in a relationship were included in the analysis within the scope of the present study. Single women who had never been in a relationship were excluded from the study. The demographic characteristics of the women who participated in the research are presented in Table 1.

\section{Variables}

According to The National Research on Domestic Violence against Women in Turkey the following questions related to sexual violence were directed to the participating women: "Has your husband or one of your intimate partners exerted physical force to have intercourse with you?", "Have you involuntarily engaged in sexual intercourse because of fear of potential threats from your husband or one of your intimate partners?" and "Has your husband or one of your intimate partners force you to perform a sexually demeaning or disgraceful act?" The women's experiences of sexual violence measured by these questions were used to create a dependent variable. If the participating women had experienced one or many of the above-mentioned cases, they were deemed to be a victim of husband/partner-inflicted sexual violence, however, if none of the cases were experienced, they were deemed to have not experienced sexual violence. Thus, the dependent variable code 1 was assigned to women who had experienced sexual violence and the dependent variable code 0 was assigned to those who had not.

\section{Data sources/measurement}

In this study, the cross-sectional data of the National Research on Domestic Violence against Women in Turkey conducted in 2008 and 2014 by the Institute of Population Studies of Hacettepe University were used.
Table 1 Demographic characteristics of the participants

\begin{tabular}{|c|c|c|}
\hline Variables & Frequencies & $\%$ \\
\hline \multicolumn{3}{|l|}{ Region } \\
\hline TR1 & 1399 & 7.6 \\
\hline TR2/TR4 & 3075 & 16.6 \\
\hline TR3 & 1517 & 8.2 \\
\hline TR6 & 1614 & 8.7 \\
\hline TR5/TR7 & 2922 & 15.8 \\
\hline TR8/TR9 & 2962 & 16.0 \\
\hline TRC & 1734 & 9.4 \\
\hline TRA/TRB & 3288 & 17.8 \\
\hline \multicolumn{3}{|l|}{ Place of residence } \\
\hline Rural & 5158 & 27.9 \\
\hline Urban & 13,353 & 72.1 \\
\hline \multicolumn{3}{|l|}{ Age } \\
\hline $15-24$ years & 2795 & 15.1 \\
\hline $25-34$ years & 5855 & 31.6 \\
\hline $35-44$ years & 4890 & 26.4 \\
\hline $45-54$ years & 3630 & 19.6 \\
\hline $55+$ years & 1341 & 7.2 \\
\hline \multicolumn{3}{|l|}{ Level of education } \\
\hline Illiterate & 3010 & 16.3 \\
\hline Elementary school graduate & 8986 & 48.6 \\
\hline Secondary school graduate & 1820 & 9.8 \\
\hline High school graduate & 2975 & 16.1 \\
\hline University graduate & 1717 & 9.3 \\
\hline \multicolumn{3}{|l|}{ Employment } \\
\hline Unemployed & 14,635 & 79.1 \\
\hline Employed & 3876 & 20.9 \\
\hline \multicolumn{3}{|l|}{ Marital status } \\
\hline Single & 1433 & 7.7 \\
\hline Married & 15,925 & 86.0 \\
\hline Widowed/divorced/separated & 1153 & 6.2 \\
\hline \multicolumn{3}{|l|}{ Number of children } \\
\hline No children & 2689 & 14.5 \\
\hline One child & 2901 & 15.7 \\
\hline Two or more children & 12,921 & 69.8 \\
\hline
\end{tabular}

The survey questionnaires of The National Research on Domestic Violence against Women in Turkey were implemented by the research team. Ethical rules developed by the WHO were followed at every stage of the study, and various measures were taken to ensure the safety of both the participating women and the research team. Written consent was obtained from the participants before each interview. The researchers received traing on Ethical and Safety Rules, and conducted themselves in accordance with sensitivity of the subject at the beginning, during and after the interview process. The interviews were conducted with one woman from each household. In the 
event of there being more than one woman in the 15-59 age group in the household, the participating woman was chosen by using a random method in order not to ask the same questions to more than one woman in the same household. The researchers were very meticulous in ensuring that the interviews were conducted in an isolated environment. Moreover, all interviewers were trained on the confidentiality of the interviews. During the process of obtaining consent and providing information regarding the content of the study, the participants were informed that their answers would be kept confidential $[22,23]$.

\section{Bias}

The data regarding women's history of exposure to sexual violence were the subjective responses of women. Thus, there was a decided risk that any data obtained by this method could be biased.

\section{Study size}

In the research conducted in 2008, the questionnaire was completed by interviewing 12,795 women face to face and the rejection rate was $2.1 \%$. The response rate for the interviews conducted with the women was $86.1 \%$ [22]. In the research conducted in 2014, the questionnaire was completed by interviewing 7462 women face to face, and the rejection rate was $4.4 \%$. The response rate for the interviews conducted with the women is $83.3 \%$ [23]. The weights calculated in accordance with the sample design of the research were added to these data sets $[22,23]$.

\section{Quantitative variables}

In this study, questions related to sociodemographic and economic characteristics and domestic violence were directed to the participants, and some of the variables thought to be influential were then integrated into the model. The variables of the socio-demographic and economic characteristics of the women were determined as survey year $(2008,2014)$, place of residence (rural, urban), age (15-24, 25-34, 35-44, 45-54, 55 and above), level of education (illiterate, elementary school graduate, secondary school graduate, high school graduate, university graduate), employment status (employed, unemployed), marital status (single, married, widowed/divorced/separated), health condition (bad/very bad, not bad, perfect/good), number of children (no children, one child, two or more children), and exposure to first-degree relative violence (no, yes). Factors related to the woman's husband/partner were husband/partner's level of education (illiterate, elementary school graduate, secondary school graduate, high school graduate, university graduate), husband/partner's job status (unemployed, public sector, private sector), husband/partner's alcohol usage (no, yes), husband/partner's gambling history (no, yes), husband/partner's drug usage (no, yes), husband/partner's infidelity (no, yes), exposure to husband/partner's economic violence (no, yes), exposure to husband/partner's verbal abuse (no, yes), and exposure to husband/ partner's physical violence (no, yes).

The region variable was one of the independent variables in the study. At the basis of employing the Nomenclature of Units for Territorial Statistics (NUTS) in Turkey lies the obligation to establish Development Agencies [4]. Following the nomenclature of units for territorial statistics at Level 1, Turkey was divided into 12 regions. In order to obtain more meaningful results from the analysis, some of the regions were unified and then grouped into eight regions [16]. These regions and the cities within the regions are depicted in detail in Table 2.

All of the analyzed variables were categorical variables and nominal or ordinary scales. Ordinal and nominal variables were described as dummy variables in order to observe the impact of the categories belonging to all the

Table 2 Statistical region units classification -Level 1

\begin{tabular}{|c|c|c|}
\hline Code & Level 1 & Provinces \\
\hline TR1 & 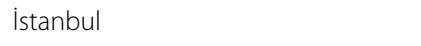 & İstanbul \\
\hline TR2/TR4 & West Marmara/East Marmara & $\begin{array}{l}\text { Tekirdağ, Edirne, Kırklareli, Balıkesir, Çanakkale, Bursa, Eskişehir, Bilecik, Kocaeli, Sakarya, Düzce, Bolu, } \\
\text { Yalova }\end{array}$ \\
\hline TR3 & Aegean & İzmir, Aydın, Denizli, Muğla, Manisa, Afyonkarahisar, Kütahya, Uşak \\
\hline TR5/TR7 & Western Anatolia/Central Anatolia & Ankara, Konya, Karaman, Kırıkkale, Aksaray, Niğde, Nevşehir, Kırşehir, Kayseri, Sivas, Yozgat \\
\hline TR6 & Mediterranean & Antalya, Isparta, Burdur, Adana, Mersin, Hatay, Kahramanmaraş, Osmaniye \\
\hline TR8/TR9 & West Blacksea/East Blacksea & $\begin{array}{l}\text { Zonguldak, Karabük, Bartın, Kastamonu, Çankırı, Sinop, Samsun, Tokat, Çorum, Amasya, Trabzon, Ordu, } \\
\text { Giresun, Rize, Artvin, Gümüşhane }\end{array}$ \\
\hline TRA/TRB & Northeastern Anatolia/East Anatolia & $\begin{array}{l}\text { Erzurum, Erzincan, Bayburt, Ağrı, Kars, Iğdır, Ardahan, Malatya, Elazı̆̆, Bingöl, Tunceli, Van, Muş, Bitlis, } \\
\text { Hakkâri }\end{array}$ \\
\hline TRC & Southeastern Anatolia & Gaziantep, Adıyaman, Kilis, Şanlıurfa, Diyarbakır, Mardin, Batman, Şırnak, Siirt \\
\hline
\end{tabular}


variables that would be integrated into the binary logistic regression and binary probit regression models $[5,8,9]$.

\section{Statistical methods}

Survey statistics in Stata 15 (Stata Corporation) were used to account for the complex sampling design and weights. Weighted analysis was performed. In addition, bivariate analysis was performed to identify the relationships between the dependent variable (exposure to sexual violence) and various factors. The bivariate relationships were predicted by evaluating significant differences using Pearson's chi-square tests for the categorical variables. Pearson's chi-square $\left(\chi^{2}\right)$ not only provides information regarding the significance of the observed differences, but also provides detailed information about the categories of any differences found [7].

Binary logistic regression and binary probit regression analyses were conducted to determine the risk factors that were influential on the exposure to sexual violence. These particular analyses are used to study the relationship between the dependent variable and the independent variable(s) in cases where the result (dependent) variable has two options (binary/dichotomy). Binary logistic regression not only provides the opportunity to evaluate the statistical significance of each independent variable as a risk factor but also the opportunity to calculate the odds ratio. The cumulative logistic distribution function is used in the binary logit model and the cumulative normal distribution function $(\mathrm{CDF})$ is used in the probit model. Although the logit and probit models have qualitatively similar results, the predicted values of the two models cannot be directly compared. The fact that normal CDF contains integral calculations is cited as a factor leading to a more widespread use of logistic CDF in practice [7].

\section{Results}

\section{Characteristics of the participants}

In this section, the frequency and percentages of the independent variables related to the model to be established are provided and interpreted. In Table 3, influential factors on women's exposure to sexual violence and the chi-square test statistics are provided.

Based on the findings displayed in Table 3, the participants who took part in the research in 2008 constituted $63.3 \%$ of the sample. Women who experienced firstdegree relative violence represented $11.6 \%$ of the sample. The chi-square test statistics of all the variables were determined to be significant.

Women whose husbands/partners were illiterate made up 3.9\% of the sample, and whose husbands/partners were elementary school graduates made up $42.2 \%$ of the sample. Women whose husbands/partners were unemployed represented $18.4 \%$ of the sample, while whose husbands/partners worked in the private sector represented $67 \%$ of the sample. Women whose husbands/ partners drank alcohol constituted $20.7 \%$ of the sample, and whose husbands/partners gambled constituted 2.1\% of the sample. Women whose husbands/partners were unfaithful constituted $8.9 \%$ of the sample. Women who had experienced economic violence formed $27.7 \%$ of the sample, women who had experienced verbal abuse formed $43.2 \%$ of the sample and women who had experienced physical violence represented $36.6 \%$ of the sample.

\section{Multivariate analyses}

In this study, the binary logistic regression and binary probit regression models were employed to determine the factors that influenced the likelihood of women experiencing sexual violence. The results of the estimated model are given in Table 4 .

\section{Average direct elasticities}

The marginal impacts of the factors influencing women's history of sexual violence can be seen in Table 5. In the model created in the study, the existence of multicollinearity between the independent variables was also checked, and it was suggested that a variance inflation factor (VIF) value of five and above caused a moderate level of multicollinearity, while a level of 10 and above caused a high level of multicollinearity $[5,9]$. The VIF results displayed in Table 5 indicated that there was none of the variables could cause a multicollinearity problem.

Table 5 presents the goodness of fit of the estimated models, which revealed that the results obtained from both models were identical. The accurate classification of the binary logistics and binary probit models was computed as $86.94 \%$ and $86.83 \%$, respectively. The fitness criteria for the model provided similar results for both models and were in an acceptable range for these kind of models.

According to the results of the binary logistics model presented in Table 5, women who participated in the research in 2014 were $26.47 \%$ less likely to face sexual violence from their husbands/partners compared to women who participated in the research in 2008 . Women residing in the TRA/TRB region were $43.16 \%$ more likely to face sexual violence compared to women residing in the TR1 region. Women residing in the urban area were 9.7\% less likely to face sexual violence compared to others. Women in the age group of 35-44 years were $26.4 \%$ less likely to face sexual violence compared to women in the age group of 15-24 years. Women who had never attended school were $32.7 \%$ more likely to face sexual violence compared to women who graduated from a university. Employed women were $16.4 \%$ more likely to 
Table 3 Distributions and chi-square test statistics of the factors influencing women's exposure to sexual violence

\begin{tabular}{|c|c|c|c|c|c|}
\hline \multirow[t]{2}{*}{ Variables } & \multicolumn{2}{|c|}{ History of experiencing sexual violence } & \multirow[t]{2}{*}{ n (\%) } & \multirow[t]{2}{*}{$x^{2}$} & \multirow[t]{2}{*}{$P$} \\
\hline & No & Yes & & & \\
\hline \multicolumn{6}{|l|}{ Survey year } \\
\hline 2008 & $9849(62)$ & $1867(71.4)$ & $11,716(63.3)$ & \multirow[t]{2}{*}{86.62} & \multirow[t]{2}{*}{$<.001$} \\
\hline 2014 & $6048(38)$ & $747(28.6)$ & $6795(36.7)$ & & \\
\hline \multicolumn{6}{|l|}{ Health condition } \\
\hline Perfect/good & $7341(46.2)$ & $725(27.7)$ & $8066(43.6)$ & \multirow[t]{3}{*}{503.99} & \multirow[t]{3}{*}{$<.001$} \\
\hline Not bad & $6533(41.1)$ & $1177(45)$ & $7710(41.7)$ & & \\
\hline Bad/very bad & $2018(12.7)$ & $711(27.2)$ & $2729(14.7)$ & & \\
\hline \multicolumn{6}{|l|}{ First-degree relative violence } \\
\hline No & $14,258(89.7)$ & $2104(80.6)$ & $16,362(88.4)$ & \multirow[t]{2}{*}{183.29} & \multirow[t]{2}{*}{$<.001$} \\
\hline Yes & $1637(10.3)$ & $508(19.4)$ & $2145(11.6)$ & & \\
\hline \multicolumn{6}{|c|}{ Husband/partner's level of education } \\
\hline Illiterate & $538(3.4)$ & $191(7.3)$ & $729(3.9)$ & \multirow[t]{5}{*}{343.68} & \multirow[t]{5}{*}{$<.001$} \\
\hline Elementary school graduate & $6434(40.5)$ & $1376(52.7)$ & $7810(42.2)$ & & \\
\hline Secondary school graduate & $2288(14.4)$ & $404(15.5)$ & $2692(14.6)$ & & \\
\hline High school graduate & $4044(25.5)$ & $438(16.8)$ & $4482(24.2)$ & & \\
\hline University graduate & $2578(16.2)$ & $204(7.8)$ & $2782(15)$ & & \\
\hline \multicolumn{6}{|c|}{ Husband/partner's employment status } \\
\hline Unemployed & $2831(17.8)$ & $572(21.9)$ & $2403(18.4)$ & \multirow[t]{3}{*}{43.37} & \multirow[t]{3}{*}{$<.001$} \\
\hline Public sector & $2404(15.1)$ & $294(11.2)$ & $2698(14.6)$ & & \\
\hline Private sector & $10,647(67)$ & $1748(66.9)$ & $12,395(67)$ & & \\
\hline \multicolumn{6}{|l|}{ Husband/partner's alcohol usage } \\
\hline No & $12,770(80.4)$ & $1897(72.6)$ & $14,667(79.3)$ & \multirow[t]{2}{*}{82.97} & \multirow[t]{2}{*}{$<.001$} \\
\hline Yes & $3120(19.6)$ & $717(27.4)$ & $3837(20.7)$ & & \\
\hline \multicolumn{6}{|c|}{ Husband/partner's gambling history } \\
\hline No & $15,661(98.6)$ & $2456(94)$ & $18,117(97.9)$ & \multirow[t]{2}{*}{232.762} & $<.001$ \\
\hline Yes & $226(1.4)$ & $157(6)$ & $383(2.1)$ & & \\
\hline Husband/partner's drug usage & & & & & \\
\hline No & $15,831(99.7)$ & $2576(98.6)$ & 18,407 (99.6) & 65.180 & $<.001$ \\
\hline Yes & $45(0.3)$ & $37(1.4)$ & $82(0.4)$ & & \\
\hline Husband/partner's infidelity & & & & & \\
\hline No & $14,819(93.3)$ & $2028(77.6)$ & $16,847(91.1)$ & 681.902 & $<.001$ \\
\hline Yes & $1059(6.7)$ & $584(22.4)$ & $1643(8.9)$ & & \\
\hline Exposure to economic violence & & & & & \\
\hline No & $11,966(76.6)$ & $1211(46.5)$ & $13,177(72.3)$ & 1016.10 & $<.001$ \\
\hline Yes & $3646(23.4)$ & $1395(53.5)$ & $5041(27.7)$ & & \\
\hline Exposure to verbal abuse & & & & & \\
\hline No & $10,141(63.8)$ & $365(14)$ & $10,506(56.8)$ & 2270.96 & $<.001$ \\
\hline Yes & $5956(36.2)$ & $2249(86)$ & $8005(43.2)$ & & \\
\hline Exposure to physical violence & & & & & \\
\hline No & $11,276(70.9)$ & $451(17.3)$ & $11,727(63.4)$ & 2785.97 & $<.001$ \\
\hline Yes & $4621(29.1)$ & $2163(82.7)$ & $6784(36.6)$ & & \\
\hline
\end{tabular}

face sexual violence compared to unemployed women. Women who had never been married were $148.1 \%$ less likely to face sexual violence from a husband/partner compared to women who were widowed/divorced/separated. Women with an excellent/good health condition were $25.3 \%$ less likely to face sexual violence compared to women with a poor/very poor health condition. Women who had children were $24.5 \%$ less likely to face sexual violence compared to women who had no children. Women who had been exposed to first degree relative violence, 
Table 4 Estimated model results of the influential factors in women's exposure to sexual violence

\begin{tabular}{|c|c|c|c|c|c|c|c|c|}
\hline \multirow[t]{3}{*}{ Variables } & \multicolumn{4}{|c|}{ Binary logistic regression } & \multicolumn{4}{|c|}{ Binary probit regression } \\
\hline & \multirow[t]{2}{*}{$\beta$} & \multirow[t]{2}{*}{ Std. Error } & \multicolumn{2}{|l|}{$95 \% \mathrm{Cl}$} & \multirow[t]{2}{*}{$\beta$} & \multirow[t]{2}{*}{ Std. Error } & \multicolumn{2}{|l|}{$95 \% \mathrm{Cl}$} \\
\hline & & & Lower & Upper & & & Lower & Upper \\
\hline \multicolumn{9}{|c|}{ Survey year (reference category: 2008) } \\
\hline 2014 & $-0.303^{\mathrm{a}}$ & 0.066 & -0.432 & -0.174 & $-0.171^{\mathrm{a}}$ & 0.036 & -0.242 & -0.100 \\
\hline \multicolumn{9}{|l|}{ Region (reference category: TR1) } \\
\hline $\mathrm{TR} 2 / \mathrm{TR} 4$ & 0.069 & 0.128 & -0.181 & 0.319 & 0.037 & 0.069 & -0.099 & 0.173 \\
\hline TR3 & 0.191 & 0.140 & -0.084 & 0.466 & 0.106 & 0.076 & -0.044 & 0.255 \\
\hline TR6 & 0.091 & 0.134 & -0.173 & 0.355 & 0.044 & 0.074 & -0.100 & 0.189 \\
\hline TR5/TR7 & $0.249^{b}$ & 0.123 & 0.008 & 0.490 & $0.145^{b}$ & 0.068 & 0.012 & 0.278 \\
\hline TR8/TR9 & $0.261^{b}$ & 0.127 & 0.011 & 0.510 & $0.144^{b}$ & 0.069 & 0.008 & 0.280 \\
\hline TRC & 0.203 & 0.134 & -0.059 & 0.465 & 0.124 & 0.073 & -0.020 & 0.268 \\
\hline TRA/TRB & $0.501^{\mathrm{a}}$ & 0.124 & 0.258 & 0.744 & $0.283^{\mathrm{a}}$ & 0.068 & 0.150 & 0.417 \\
\hline \multicolumn{9}{|c|}{ Place of residence (reference category: rural) } \\
\hline Urban & $-0.112^{c}$ & 0.066 & -0.242 & 0.018 & $-0.063^{c}$ & 0.036 & -0.134 & 0.009 \\
\hline \multicolumn{9}{|c|}{ Age (reference category: 15-24 years) } \\
\hline $25-34$ years & $-0.236^{c}$ & 0.127 & -0.484 & 0.013 & $-0.122^{c}$ & 0.069 & -0.257 & 0.012 \\
\hline $35-44$ years & $-0.305^{b}$ & 0.136 & -0.571 & -0.038 & $-0.162^{b}$ & 0.074 & -0.308 & -0.016 \\
\hline $45-54$ years & -0.085 & 0.143 & -0.365 & 0.195 & -0.039 & 0.077 & -0.190 & 0.113 \\
\hline $55+$ years & -0.137 & 0.167 & -0.464 & 0.191 & -0.071 & 0.091 & -0.249 & 0.108 \\
\hline \multicolumn{9}{|c|}{ Level of education (reference category: university) } \\
\hline Illiterate & $0.374^{c}$ & 0.203 & -0.024 & 0.772 & $0.206^{c}$ & 0.107 & -0.004 & 0.416 \\
\hline Elementary school graduate & 0.266 & 0.188 & -0.102 & 0.634 & 0.151 & 0.098 & -0.041 & 0.343 \\
\hline Secondary school graduate & 0.206 & 0.204 & -0.194 & 0.606 & 0.124 & 0.108 & -0.087 & 0.335 \\
\hline High school graduate & 0.150 & 0.190 & -0.222 & 0.523 & 0.081 & 0.099 & -0.112 & 0.274 \\
\hline \multicolumn{9}{|c|}{ Employment (reference category: unemployed) } \\
\hline Employed & $0.190^{b}$ & 0.077 & 0.039 & 0.341 & $0.103^{b}$ & 0.043 & 0.019 & 0.187 \\
\hline \multicolumn{9}{|c|}{ Marital status (reference category: widowed/divorced/separated) } \\
\hline Single & $-1.650^{\mathrm{a}}$ & 0.335 & -2.306 & -0.994 & $-0.846^{\mathrm{a}}$ & 0.162 & -1.164 & -0.528 \\
\hline Married & $-0.422^{\mathrm{a}}$ & 0.105 & -0.628 & -0.216 & $-0.246^{\mathrm{a}}$ & 0.060 & -0.364 & -0.129 \\
\hline \multicolumn{9}{|c|}{ Health condition (reference category: bad/very bad) } \\
\hline Perfect/good & $-0.293^{\mathrm{a}}$ & 0.090 & -0.469 & -0.116 & $-0.161^{\mathrm{a}}$ & 0.050 & -0.259 & -0.063 \\
\hline Not bad & $-0.225^{\mathrm{a}}$ & 0.081 & -0.383 & -0.066 & $-0.123^{\mathrm{a}}$ & 0.046 & -0.213 & -0.033 \\
\hline \multicolumn{9}{|c|}{ Number of children (reference category: no children) } \\
\hline One child & $-0.279^{c}$ & 0.151 & -0.574 & 0.016 & $-0.150^{c}$ & 0.080 & -0.307 & 0.006 \\
\hline Two or more children & 0.016 & 0.136 & -0.251 & 0.283 & 0.007 & 0.073 & -0.136 & 0.149 \\
\hline \multicolumn{9}{|c|}{ Exposure to first-degree relative violence (reference category: no) } \\
\hline Yes & $0.307^{\mathrm{a}}$ & 0.085 & 0.141 & 0.473 & $0.176^{\mathrm{a}}$ & 0.048 & 0.081 & 0.270 \\
\hline \multicolumn{9}{|c|}{ Husband/partner's level of education (reference category: elementary school) } \\
\hline Illiterate & $0.438^{\mathrm{a}}$ & 0.138 & 0.168 & 0.707 & $0.236^{\mathrm{a}}$ & 0.077 & 0.085 & 0.386 \\
\hline Secondary school graduate & -0.053 & 0.092 & -0.234 & 0.127 & -0.024 & 0.051 & -0.125 & 0.076 \\
\hline High school graduate & $-0.202^{b}$ & 0.092 & -0.383 & -0.022 & $-0.115^{b}$ & 0.050 & -0.213 & -0.016 \\
\hline University graduate & -0.127 & 0.140 & -0.401 & 0.147 & -0.078 & 0.075 & -0.225 & 0.068 \\
\hline Husband/partner's employme & atus (refere & category: pu & sector) & & & & & \\
\hline Unemployed & $0.308^{b}$ & 0.119 & 0.075 & 0.541 & $0.176^{\mathrm{a}}$ & 0.065 & 0.048 & 0.303 \\
\hline Private sector & 0.106 & 0.103 & -0.097 & 0.309 & 0.058 & 0.056 & -0.051 & 0.167 \\
\hline Husband/partner's alcohol usa & eference c & ory: no) & & & & & & \\
\hline Yes & 0.069 & 0.077 & -0.082 & 0.220 & 0.036 & 0.043 & -0.048 & 0.119 \\
\hline Husband/partner's gambling & $y$ (referenc & tegory: no) & & & & & & \\
\hline Yes & 0.216 & 0.156 & -0.089 & 0.521 & 0.146 & 0.091 & -0.033 & 0.325 \\
\hline
\end{tabular}


Table 4 (continued)

\begin{tabular}{|c|c|c|c|c|c|c|c|c|}
\hline \multirow[t]{3}{*}{ Variables } & \multicolumn{4}{|c|}{ Binary logistic regression } & \multicolumn{4}{|c|}{ Binary probit regression } \\
\hline & \multirow[t]{2}{*}{$\beta$} & \multirow[t]{2}{*}{ Std. Error } & \multicolumn{2}{|l|}{$95 \% \mathrm{Cl}$} & \multirow[t]{2}{*}{$\beta$} & \multirow[t]{2}{*}{ Std. Error } & \multicolumn{2}{|l|}{$95 \% \mathrm{Cl}$} \\
\hline & & & Lower & Upper & & & Lower & Upper \\
\hline \multicolumn{9}{|c|}{ Husband/partner's drug usage (reference category: no) } \\
\hline Yes & $0.730^{\mathrm{a}}$ & 0.281 & 0.179 & 1.281 & $0.435^{\mathrm{a}}$ & 0.167 & 0.108 & 0.762 \\
\hline \multicolumn{9}{|c|}{ Husband/partner's infidelity (reference category: no) } \\
\hline Yes & $0.493^{\mathrm{a}}$ & 0.085 & 0.327 & 0.660 & $0.299^{\mathrm{a}}$ & 0.050 & 0.202 & 0.397 \\
\hline \multicolumn{9}{|c|}{ Exposure to economic violence (reference category: no) } \\
\hline Yes & $0.728^{\mathrm{a}}$ & 0.065 & 0.601 & 0.855 & $0.402^{\mathrm{a}}$ & 0.036 & 0.332 & 0.473 \\
\hline \multicolumn{9}{|c|}{ Exposure to verbal abuse (reference category: no) } \\
\hline Yes & $1.394^{\mathrm{a}}$ & 0.086 & 1.226 & 1.563 & $0.710^{\mathrm{a}}$ & 0.042 & 0.628 & 0.792 \\
\hline \multicolumn{9}{|c|}{ Exposure to physical violence (reference category: no) } \\
\hline Yes & $1.450^{\mathrm{a}}$ & 0.082 & 1.289 & 1.611 & $0.766^{\mathrm{a}}$ & 0.041 & 0.686 & 0.846 \\
\hline Constant & $-3.550^{\mathrm{a}}$ & 0.316 & -4.169 & -2.932 & $-1.914^{\mathrm{a}}$ & 0.167 & -2.242 & -1.586 \\
\hline
\end{tabular}

those whose husbands/partners used drugs, those whose husbands/partners had been unfaithful, those who had been subjected to economic violence by their husbands/ partners, those who had been exposed to verbal violence by their husbands/partner, those who had been subjected to physical violence by their husbands/partners were $26.4 \%, 60.98 \%, 42.13 \%, 62.96 \%, 124.33 \%$ and $128.46 \%$ more likely to face sexual violence compared to other women, respectively. Women whose husbands/partners had not attended school were $37.01 \%$ more likely to face sexual violence compared to those whose husbands/partners were primary school graduates. Women whose husbands/partners were unemployed were $26.7 \%$ more likely to face sexual violence compared to those whose husbands/partner worked in the public sector.

According to the binary probit model results presented in Table 5, women who participated in the study in 2014 were $34.45 \%$ less likely to face sexual violence from their husbands/partners compared to the women who participated in the study in 2008. Women residing in the TRA/ TRB region were $55.15 \%$ more likely to face sexual violence compared to women residing in the TR1 region. Women residing in the urban area were $12.39 \%$ less likely to face sexual violence compared to others. Women in the age group of $35-44$ years were $32.17 \%$ less likely to face sexual violence compared to women in the age group of 15-24 years. Women who had never attended school were $41.43 \%$ more likely to face sexual violence compared to women who had graduated from university. Employed women were $20.27 \%$ more likely to face sexual violence compared to unemployed women. Women who had never been married were $178.42 \%$ less likely to face sexual violence from a husband/partner compared to women who were widowed/divorced/separated. Woman with an excellent/good health condition were $31.43 \%$ less likely to face sexual violence compared to women with a poor/very poor health condition. Women with children were $30.59 \%$ less likely to face sexual violence compared to women who did not. Women who had been exposed to first degree relative violence, those whose husbands/ partners used drugs, those whose husbands/partners had been unfaithful, those who had been subjected to economic violence by their husbands/partners, those who had been exposed to verbal violence by their husbands/ partners and those who had been subjected to physical violence by their husbands/partners were $33.97 \%$, $78.99 \%, 56.495 \%, 76.98 \%, 137.17 \%$ and $144.13 \%$ more likely to face sexual violence compared to other women. Women whose husbands/partners had not attended school were $43.93 \%$ more likely to face sexual violence compared to those whose husbands/partners were primary school graduates. Women whose husbands/partners were unemployed were $34.7 \%$ more likely to face sexual violence compared to those whose husbands/partners worked in the public sector.

\section{Discussion}

In this study, the factors that influenced sexual violence against women in Turkey were investigated by employing binary logistic and binary probit regression analyses. According to the results of the analyses, women who participated in the questionnaire in 2014 were less likely to experience sexual violence compared compared to women who had participated in the 2008 questionnaire. It can be stated that the legal regulations adopted for the 
Table 5 Average elasticity values of the factors influential in women's exposure to sexual violence

\begin{tabular}{|c|c|c|c|c|c|c|}
\hline \multirow[t]{2}{*}{ Variables } & \multicolumn{2}{|c|}{ Binary logistic regression } & \multicolumn{2}{|c|}{ Binary probit regression } & \multirow[t]{2}{*}{ VIF } & \multirow[t]{2}{*}{$1 / \mathrm{VIF}$} \\
\hline & Elasticity (\%) & Std. Error & Elasticity (\%) & Std. Error & & \\
\hline \multicolumn{7}{|c|}{ Survey year (reference category: 2008) } \\
\hline 2014 & $-26.466^{\mathrm{a}}$ & 0.058 & -34.445 & 0.074 & 1.040 & 0.958 \\
\hline \multicolumn{7}{|l|}{ Region (reference category: TR1) } \\
\hline TR2/TR4 & 6.083 & 0.112 & 7.559 & 0.142 & 2.720 & 0.367 \\
\hline TR3 & 16.740 & 0.123 & 21.345 & 0.154 & 1.960 & 0.511 \\
\hline TR6 & 7.997 & 0.118 & 9.027 & 0.151 & 1.990 & 0.502 \\
\hline TR5/TR7 & $21.717^{b}$ & 0.108 & $29.054^{b}$ & 0.137 & 2.650 & 0.377 \\
\hline TR8/TR9 & $22.737^{b}$ & 0.111 & $28.876^{b}$ & 0.141 & 2.710 & 0.369 \\
\hline TRC & 17.757 & 0.117 & 24.915 & 0.149 & 2.160 & 0.463 \\
\hline TRA/TRB & $43.159^{\mathrm{a}}$ & 0.108 & $55.149^{\mathrm{a}}$ & 0.136 & 2.930 & 0.342 \\
\hline \multicolumn{7}{|c|}{ Place of residence (reference category: rural) } \\
\hline Urban & $-9.691^{c}$ & 0.057 & -12.385 & $0.071^{c}$ & 1.140 & 0.874 \\
\hline \multicolumn{7}{|c|}{ Age (reference category: 15-24 years) } \\
\hline 25-34 years & $-20.356^{c}$ & 0.109 & $-24.064^{c}$ & 0.134 & 3.100 & 0.323 \\
\hline $35-44$ years & $-26.390^{b}$ & 0.117 & $-32.166^{b}$ & 0.146 & 3.320 & 0.301 \\
\hline $45-54$ years & -7.295 & 0.122 & -7.462 & 0.149 & 3.140 & 0.318 \\
\hline $55+$ years & -11.750 & 0.143 & -13.766 & 0.177 & 2.050 & 0.487 \\
\hline \multicolumn{7}{|c|}{ Level of education (reference category: university graduate) } \\
\hline Illiterate & $32.711^{c}$ & 0.179 & $41.427^{c}$ & 0.220 & 4.320 & 0.231 \\
\hline Elementary school graduate & 23.362 & 0.167 & 30.789 & 0.203 & 5.730 & 0.175 \\
\hline Secondary school graduate & 18.144 & 0.181 & 25.321 & 0.222 & 2.490 & 0.402 \\
\hline High school graduate & 13.288 & 0.169 & 16.700 & 0.205 & 2.800 & 0.357 \\
\hline \multicolumn{7}{|c|}{ Employment (reference category: unemployed) } \\
\hline Employed & $16.433^{b}$ & 0.066 & $20.273^{b}$ & 0.083 & 1.150 & 0.872 \\
\hline \multicolumn{7}{|c|}{ Marital status (reference category: widowed/divorced/separated) } \\
\hline Single & $-148.104^{\mathrm{a}}$ & 0.314 & $-178.415^{\mathrm{a}}$ & 0.386 & 3.080 & 0.324 \\
\hline Married & $-35.862^{\mathrm{a}}$ & 0.088 & $-45.788^{\mathrm{a}}$ & 0.106 & 2.150 & 0.466 \\
\hline \multicolumn{7}{|c|}{ Health condition (reference category: bad/very bad) } \\
\hline Perfect/good & $-25.292^{\mathrm{a}}$ & 0.078 & $-31.430^{\mathrm{a}}$ & 0.096 & 2.670 & 0.375 \\
\hline Not bad & $-19.346^{\mathrm{a}}$ & 0.069 & $-23.895^{\mathrm{a}}$ & 0.088 & 2.370 & 0.422 \\
\hline \multicolumn{7}{|c|}{ Number of children (reference category: no children) } \\
\hline One child & $-24.535^{c}$ & 0.132 & $-30.591^{c}$ & 0.161 & 2.820 & 0.354 \\
\hline Two or more children & 1.415 & 0.118 & 1.290 & 0.143 & 3.790 & 0.264 \\
\hline \multicolumn{7}{|c|}{ Exposure to first-degree relative violence (reference category: no) } \\
\hline Yes & $26.417^{\mathrm{a}}$ & 0.072 & $33.965^{\mathrm{a}}$ & 0.091 & 1.040 & 0.960 \\
\hline \multicolumn{7}{|c|}{ Husband/partner's level of education (reference category: elementary school graduate) } \\
\hline Illiterate & $37.007^{\mathrm{a}}$ & 0.114 & $43.925^{\mathrm{a}}$ & 0.137 & 1.160 & 0.863 \\
\hline Secondary school graduate & -4.641 & 0.080 & -4.767 & 0.101 & 1.230 & 0.813 \\
\hline High school graduate & $-17.698^{b}$ & 0.081 & $-23.014^{b}$ & 0.101 & 1.530 & 0.652 \\
\hline University graduate & -11.069 & 0.122 & -15.610 & 0.151 & 2.110 & 0.473 \\
\hline \multicolumn{7}{|c|}{ Husband/partner's employment status (reference category: public sector) } \\
\hline Unemployed & $26.696^{\mathrm{b}}$ & 0.104 & $34.702^{\mathrm{a}}$ & 0.130 & 2.150 & 0.465 \\
\hline Private sector & 9.286 & 0.091 & 11.719 & 0.114 & 2.200 & 0.455 \\
\hline \multicolumn{7}{|c|}{ Husband/partner's alcohol usage (reference category: no) } \\
\hline Yes & 5.999 & 0.067 & 7.050 & 0.084 & 1.180 & 0.850 \\
\hline \multicolumn{7}{|c|}{ Husband/partner's gambling history (reference category: no) } \\
\hline Yes & 18.574 & 0.132 & 28.190 & 0.171 & 1.070 & 0.934 \\
\hline
\end{tabular}


Table 5 (continued)

\begin{tabular}{|c|c|c|c|c|c|c|}
\hline \multirow[t]{2}{*}{ Variables } & \multicolumn{2}{|c|}{ Binary logistic regression } & \multicolumn{2}{|c|}{ Binary probit regression } & \multirow[t]{2}{*}{ VIF } & \multirow[t]{2}{*}{$1 / \mathrm{VIF}$} \\
\hline & Elasticity (\%) & Std. Error & Elasticity (\%) & Std. Error & & \\
\hline \multicolumn{7}{|c|}{ Husband/partner's drug usage (reference category: no) } \\
\hline Yes & $60.976^{\mathrm{a}}$ & 0.225 & $78.987^{\mathrm{a}}$ & 0.275 & 1.030 & 0.971 \\
\hline \multicolumn{7}{|c|}{ Husband/partner's infidelity (reference category: no) } \\
\hline Yes & $42.132^{\mathrm{a}}$ & 0.071 & $56.495^{\mathrm{a}}$ & 0.089 & 1.150 & 0.869 \\
\hline \multicolumn{7}{|c|}{ Exposure to economic violence (reference category: no) } \\
\hline Yes & $62.957^{\mathrm{a}}$ & 0.056 & $76.978^{\mathrm{a}}$ & 0.068 & 1.160 & 0.866 \\
\hline \multicolumn{7}{|c|}{ Exposure to verbal abuse (reference category: no) } \\
\hline Yes & $124.329^{a}$ & 0.079 & $137.174^{\mathrm{a}}$ & 0.085 & 1.440 & 0.695 \\
\hline \multicolumn{7}{|c|}{ Exposure to physical violence (reference category: no) } \\
\hline Yes & $128.457^{\mathrm{a}}$ & 0.074 & $144.131^{\mathrm{a}}$ & 0.077 & 1.510 & 0.662 \\
\hline Pseudo $R^{2}$ & 0.274 & 0.275 & & & & \\
\hline Cox-Snell/M & 0.201 & 0.202 & & & & \\
\hline AIC & $10,892.562$ & $10,884.229$ & & & & \\
\hline $\mathrm{BIC}$ & $11,197.012$ & $11,188.679$ & & & & \\
\hline Log-likelihood & -5407.281 & -5403.114 & & & & \\
\hline Classification success & 86.94 & 86.83 & & & & \\
\hline$p$ value & 0.000 & 0.000 & & & & \\
\hline N & 18,150 & 18,150 & & & & \\
\hline
\end{tabular}

${ }^{\mathrm{a}} p<0.01,{ }^{\mathrm{b}} p<0.05,{ }^{\mathrm{C}} p<0.10 ;$ Std. Error: Standard Error; VIF: Variance Inflation Factor

prevention of violence against women 2008 had a substantial influence on this decrease [23].

Based on the model estimation results, it was determined that women living in the Western Anatolia/Central Anatolia regions, the Western Black Sea/Eastern Black Sea regions, and the Northeastern Anatolia/East Central Anatolia regions were more likely to experience sexual violence compared to women living in Istanbul. In parallel with these results, in a study conducted in Turkey, it was reported that women living in eastern and southeastern regions were more likely to experience sexual violence compared to those living in western regions [58]. It is generally accepted that the above-mentioned regions are at a lower development level than Istanbul. Moreover, urban development offers opportunities to stem the tide of violence against women in terms of forbearance, access to economic sources, assets, corporate assistance and support [39].

It was determined that women living in urban regions were less likely to experience sexual violence compared to those living in rural regions. The fact that women living in urban areas have easier access to the internet, newspapers, TV, and similar media outlets and possess a higher awareness of their legal rights and the fact the these conditions mostly apply to their husbands/partners could also be factors behind this conclusion. Similarly, in a study conducted with married women in Bangladesh it was determined that the women living in rural areas were exposed to sexual violence more frequently than those living in urban areas [40]. In a Togo-based study carried out among married women, it was determined that those living in cities were less likely to experience sexual violence [45]. The economic differences between the rural and urban areas may be influential in this result. Poverty, which is prevalent more commonly in rural areas than urban areas, gives rise to domestic stress and therefore, paves the road for violence. Furthermore, the factor of isolation in rural areas decreases the chances for women exposed to violence to access assistance and thus, increases the risk of violence towards women [10]. The general acceptance of the abuse of women in rural areas and the relevant social norms that prohibit abused women from speaking publicly and pursuing social support also reduce the likelihood of women reporting abuse to law enforcement authorities [49].

Based on the age variable, it was determined that women within the age ranges of 25-34 years and 35-44 years were less likely to experience sexual violence compared to those within the age range of 15-24 years. In a USA-based study, an increase in age was reported to move in parallel with a lowering risk of sexual violence [52]. Different from this situation, it was reported in a study conducted in East India that an increase in age further increased the risk of experiencing various types of violence [12]. The correlation between sexual violence and age is quite complicated. 
The changing economic contribution of women in society is a function of time and age. It has been stated that the influence of economic contribution and age along with the changing gender roles and types of violence are required to be researched longitudinally in detail [19].

In terms of the level of education variable, it was determined that the illiterate women were more likely to experience sexual violence compared to those who were university graduates. Similar to this finding, a study carried out in Nepal determined that uneducated women were at a greater risk of sexual violence from their intimate partners compared to educated women [11]. In a study conducted in Serbia, it was determined that women with a lower level of education were more likely to experience physical or sexual violence [24]. Findings from a study conducted in various regions of India indicated that a higher level of education decreased the possibility of women experiencing violence and sexual abuse from their intimate partners [47].

In addition, it was found that women who were employed were more likely to experience sexual violence compared to those who were unemployed. In parallel with this result, a study conducted in Indonesia reported that women with financial independence were more prone to experience sexual violence [28]. Moreover, it was concluded in a study conducted in India that married women were at high risk of being exposed to both physical and sexual violence [34]. Women who earn money can be perceived and considered as a threat to male dominance in patriarchal families according to the traditional power structure [34]. Arguably, in the event that women start earning money and contributing to the household income, they gain further independence and awareness of their rights and therefore, may challenge the traditional gender norms. Husbands who become anxious about safeguarding and maintaining their authority may respond to this situation with increased violence [19].

Women who were single or married were less likely to experience sexual violence compared to those who were widowed/divorced/separated. Similar to this finding, a study based in the USA, revealed that divorced and separated women had a higher likelihood of being exposed to sexual violence compared to married women [52]. In most cases it is unlikely that married men will practice sexual violence, as marriage is based on mutual consent [14].

Women with children were less likely to experience sexual violence compared to those with no children. In parallel with this result, a study conducted in Nepal found that the absence of children in a family increased the likelihood of a women's exposure to sexual and intimate violence [11].
Women whose husbands/partners were illiterate faced a higher possibility of sexual violence than women those husbands/partners were elementary school graduates. Furthermore, women whose husbands/partners were high school graduates faced a lower possibility of sexual violence than those whose husband/partners were elementary school graduates. In a study carried out in Indonesia, it was concluded that women whose husbands had less than nine years of education faced a higher possibility of physical and sexual violence [28]. In addition, a study in Serbia revealed that the lower the husband/partner's level of education was, the higher the risk of physical or sexual violence risk for the woman became [24]. A study conducted in Ankara, Turkey concluded that, as partners' level of education increased, an inverse fall occurred in the frequency of women's exposure to sexual violence [2]. As partners with an education beyond secondary school education consider and perceive each other more as estimable, the probability of them exploiting and abusing each other could be to a lesser extent [1].

It is highly probable that women whose husbands/partners are unemployed are more likely experience sexual violence. It was reported in a study conducted in India that women whose partners were employed were less likely to be exposed to violence [34]. Similarly, it was concluded in a study conducted in Spain that the increase in male unemployment at a regional level increased the possibility of violence towards an intimate partner [50]. This is an anticipated consequence. Theoretically, male unemployment not only increases the stress but also results in further abuse and exploitation by undermining the control and economic security feelings of males and can create a further control impulsion on their partners [51]. At this point, unemployment insurance, welfare aid and entitlement programs designed to alleviate and diminish economic challenges and difficulties could be effective in reducing the violence towards intimate partners [27].

The present study determined that women whose husbands/partners used drugs were more likely to experience sexual violence. Similarly, in a study conducted in Serbia, it was determined that women whose husbands/ partners took drugs were more likely to experience sexual or physical violence [24]. Worse still is the instances where the perpetrator drugs the drink of the victim to facilitate sexual assault. In such cases, although the effects may vary based on the type of substance, it prevents the victim from resisting against sexual assault and thus, facilitate sexual assault [15].

Women whose husbands/partners were unfaithful were more likely to experience sexual violence compared to those whose husbands/partners were faithful. In a study conducted in Indonesia, it was determined that women with unfaithful husbands/partners were exposed 
to higher rates of sexual violence [28]. Additionally, a Vietnam-based study revealed that women with unfaithful husbands/partners were more prone to experiencing several types of violence including sexual violence [31]. In a study conducted in Turkey, it was determined that women with unfaithful husbands/partners were exposed to nearly twice the rate of sexual violence those whose husbands/partners were faithful were exposed to [58].

In addition, women who experienced economic, verbal, physical abuse and violence from first-degree relatives were more prone to experience sexual violence compared to those who had never experienced such forms of violence. In a study conducted on various ethnic origins in Nigeria, it was determined that domestic violence was directly correlated with physical, psychological and sexual violence [41]. According to the results obtained from a study conducted in Ankara, Turkey, 57.6\% of women who were exposed to sexual violence had also been subjected to physical violence, while $84.5 \%$ had also been subjected to economic violence, and $72.5 \%$ had also been subjected to emotional violence [2]. Furthermore, it was reported that experiencing physical violence in the past elevated the risk of exposure to sexual violence. Hence, it was concluded that violence against women is indeed a unity and violence in any form is part of a chain reaction that leads to violence in multiple forms.

This study had a number of limitations. Firstly, the data in the study were secondary data. The variables essential for performing statistical analyses consisted of the variables in the data set. However, some variables including profession and home ownership status, were missing in the data set and therefore could not be included in the analysis. Secondly, as the data was cross-sectional, the definite causal relationship between sexual violence and the related factors could not be inferred.

\section{Conclusion}

This study was conducted with women living in Turkey and used data collected on two different dates. It is suggested that the obtained findings can lead the way for other studies that harness different econometric models and variables through employing cross-sectional data sets on sexual violence in Turkey. In relation to the envisaged measures to stop violence against women, these findings can also offer guidance to the related governmental bodies. By forming multivariate models that cover all of the aforementioned types of violence, analyses could be conducted in connection with the types of violence in the future.

\section{Abbreviations}

VIF: Variance Inflation Factor; Std. Error: Standard error.

\section{Acknowledgements}

The authors would like to thank the Turkish Statistical Institute for the data. The views and opinions expressed in this manuscript are those of the authors only and do not necessarily represent the views, official policy, or position of the Turkish Statistical Institute.

\section{Authors' contributions}

ÖA conceived and led the design and development of the study proposal. ÖA and HHT supervised the data collection, led the data analysis and drafted the manuscript. HHT made substantial contributions to the conceptualization and design of the study, data interpretations and writing the manuscript. All authors read and approved the final version of the manuscript.

\section{Funding}

This research did not receive any specific grant from funding agencies in the public, commercial, or not-for-profit sectors.

\section{Availability of data and materials}

The data underlying this study is subject to third-party restrictions by the Turkey Statistical Institute. Data are available from the Turkish Statistical Institute (bilgi@tuik.gov.tr) for researchers who meet the criteria for access to confidential data. The authors of the study did not receive any special privileges in accessing the data.

\section{Declarations}

\section{Ethics approval and consent to participate}

This study was accomplished by using data of the survey titled National Research on Domestic Violence against Women in Turkey conducted by Turkey Statistical Institute. Therefore, ethical approval was not required for this study.We used secondary data for this study. In order to use the micro dataset from the National Research on Domestic Violence against Women in Turkey, the official permission was obtained from the Turkish Statistical Institute. In addition, a "Letter of Undertaking" was given to the Turkish Statistical Institute for the use of the data subjected to the study.

\section{Consent for publication}

Not applicable.

\section{Competing interests}

The authors have no competing interests to report. Additionally, the authors had full access to all of the data in the study and take responsibility for the integrity of the data and the accuracy of the data analysis.

Received: 29 June 2020 Accepted: 28 April 2021

Published online: 05 May 2021

\section{References}

1. Adjah ESO, Agbemafle I. Determinants of domestic violence against women in Ghana. BMC Public Health. 2016;16(1):1-9.

2. Akar T, Aksakal FN, Demirel B, Durukan E, Özkan S. The prevalence of domestic violence against women among a group woman: Ankara, Turkey. J Fam Violence. 2010;25(5):449-60.

3. Alan Dikmen H, Cankaya S. Associations between sexual violence and women's sexual attitudes, sexual self-consciousness, and sexual selfefficacy. J Interpers Violence. 2020. https://doi.org/10.1177/0886260519 897339.

4. Alkan Ö, Oktay E, Genç A. Determination of factors affecting the children's internet use. Am Int J Contemp Res. 2015;5(6):57-67.

5. Alkan Ö, Oktay E, Ünver \$̧, Gerni E. Determination of factors affecting the financial literacy of university students in Eastern Anatolia using ordered regression models. Asian Econ Financ Rev. 2020;10(5):536-46.

6. Alkan Ö, Özar Ş, Ünver Ş. Economic violence against women: A case in Turkey. PLoS ONE. 2021;16(3):e0248630.

7. Alkan Ö, Ünver Ş. Determinants of domestic physical violence against women in Turkey. Humanit Soc Sci Rev. 2020;8(6):55-67. 
8. Alkan Ö, Ünver Ş. Tobacco smoke exposure among women in Turkey and determinants. J Substance Use. 2021. https://doi.org/10.1080/ 14659891.2021.1885518.

9. Alkan Ö, Yılmaz FC, Abar H. Türkiye'de kadına yönelik aile içi şiddeti etkileyen faktörlerin sıralı probit regresyon modeliyle belirlenmesi [The determination of factors affecting domestic violence against women in Turkey using ordered probit regression models]. J Human Soc Sci Res. 2020;9(5):3338-60.

10. Antai D. Controlling behavior, power relations within intimate relationships and intimate partner physical and sexual violence against women in Nigeria. BMC Public Health. 2011;11(1):1-11.

11. Atteraya MS, Gnawali S, Song IH. Factors associated with intimate partner violence against married women in Nepal. J Interpers Violence. 2015;30(7):1226-46.

12. Babu BV, Kar SK. Domestic violence against women in eastern India: a population-based study on prevalence and related issues. BMC Public Health. 2009;9(1):1-15.

13. Bagwell-Gray ME, Messing JT, Baldwin-White A. Intimate partner sexual violence: a review of terms, definitions, and prevalence. Trauma Violence Abuse. 2015;16(3):316-35.

14. Banarjee $\mathrm{S}$. Identifying factors of sexual violence against women and protection of their rights in Bangladesh. Aggress Violent Beh. 2020. https://doi.org/10.1016/j.avb.2020.101384.

15. Basile KC, Smith SG. Sexual violence victimization of women: Prevalence, characteristics, and the role of public health and prevention. Am J Lifestyle Med. 2011;5(5):407-17.

16. Bilenkisi F, Gungor MS, Tapsin G. The impact of household heads' education levels on the poverty risk: the evidence from Turkey. Educ Scie Theory Pract. 2015;15(2):337-48.

17. Bott S. Sexual violence and coercion: implications for sexual and reproductive health. In: Malarcher S, editor. Social determinants of sexual and reproductive health: informing future research and programme implementation. Geneva: World Health Organization; 2010. p. 133-57.

18. Breiding MJ, Smith SG, Basile KC, Walters ML, Chen J, Merrick MT. Prevalence and characteristics of sexual violence, stalking, and intimate partner violence victimization-National Intimate Partner and Sexual Violence Survey, United States, 2011. Am J Public Health. 2015:105(4):e11-2.

19. Chibber KS, Krupp K, Padian N, Madhivanan P. Examining the determi nants of sexual violence among young, married women in Southern India. J Interpers Violence. 2012;27(12):2465-83.

20. Dartnall $E$, Jewkes $R$. Sexual violence against women: the scope of the problem. Best Pract Res Clin Obstet Gynaecol. 2013;27(1):3-13.

21. Davila AL, Johnson L, Postmus JL. Examining the relationship between economic abuse and mental health among Latina intimate partner violence survivors in the United States. J Interpers Violence. 2021;36(1-2):NP287-310.

22. DGSW. (2009). National Research on Domestic Violence against Women in Turkey. Hacettepe University Institute of Population studies, ICONInstitute Public Sector GmbH and BNB: Turkish Republic Prime Ministry Directorate General on the Status of Women (DGSW).

23. DGSW. (2014). National Research on Domestic Violence against Women in Turkey. Hacettepe University Institute of Population studies, ICONInstitute Public Sector GmbH and BNB: Turkish Republic Prime Ministry Directorate General on the Status of Women (DGSW).

24. Djikanovic B, Jansen HA, Otasevic S. Factors associated with intimate partner violence against women in Serbia: a cross-sectional study. J Epidemiol Community Health. 2010;64(8):728-35.

25. García-Moreno C, Jansen HA, Ellsberg M, Heise L, Watts C. WHO multicountry study on women's health and domestic violence against women. Geneva: World Health Organization; 2005.

26. Gokler ME, Arslantas D, Unsal A. Prevalence of domestic violence and associated factors among married women in a semi-rural area of western Turkey. Pak J Med Sci. 2014;30(5):1088.

27. Golden SD, Perreira KM, Durrance CP. Troubled times, troubled relationships: How economic resources, gender beliefs, and neighborhood disadvantage influence intimate partner violence. J Interpers Violence. 2013:28(10):2134-55.

28. Hayati EN, Högberg U, Hakimi M, Ellsberg MC, Emmelin M. Behind the silence of harmony: risk factors for physical and sexual violence among women in rural Indonesia. BMC Womens Health. 2011:11:52.
29. Ipekten Alaman M, Yıldız H. Domestic sexual violence and sexual problems among gynecology outpatients: an example from Turkey. Women Health. 2014;54(5):439-54.

30. Izmirli GO, Sonmez Y, Sezik M. Prediction of domestic violence against married women in southwestern Turkey. Int J Gynecol Obstet. 2014;127(3):288-92

31. Jansen HA, Nguyen TVN, Hoang TA. Exploring risk factors associated with intimate partner violence in Vietnam: results from a cross-sectional national survey. Int J Public Health. 2016;61(8):923-34.

32. Jina $R$, Thomas $L S$. Health consequences of sexual violence against women. Best Pract Res Clin Obstet Gynaecol. 2013;27(1):15-26.

33. Kalra G, Bhugra D. Sexual violence against women: Understanding crosscultural intersections. Indian J Psychiatry. 2013;55(3):244-9.

34. Kimuna SR, Djamba YK, Ciciurkaite G, Cherukuri S. Domestic violence in India: Insights from the 2005-2006 national family health survey. J Interpers Violence. 2013;28(4):773-807.

35. Kiss L, Schraiber LB, Heise L, Zimmerman C, Gouveia N, Watts C. Genderbased violence and socioeconomic inequalities: Does living in more deprived neighbourhoods increase women's risk of intimate partner violence? Soc Sci Med. 2012;74(8):1172-9.

36. Kocacik F, Dogan O. Domestic violence against women in Sivas, Turkey: survey study. Croat Med J. 2006;47(5):742-9.

37. Krug EG, Mercy JA, Dahlberg LL, Zwi AB. The world report on violence and health. The Lancet. 2002;360(9339):1083-8.

38. Lencha B, Ameya G, Baresa G, Minda Z, Ganfure G. Intimate partner violence and its associated factors among pregnant women in Bale Zone, Southeast Ethiopia: a cross-sectional study. PLoS ONE. 2019;14(5):e0214962.

39. Mcllwaine C. Urbanization and gender-based violence: exploring the paradoxes in the global South. Environ Urban. 2013;25(1):65-79.

40. Naved RT. Sexual violence towards married women in Bangladesh. Arch Sex Behav. 2013;42(4):595-602.

41. Nwabunike C, Tenkorang EY. Domestic and marital violence among three ethnic groups in Nigeria. J Interpers Violence. 2017;32(18):2751-76.

42. Öyekçin DG, Yetım D, Şahın EM. Psychosocial factors affecting various types of intimate partner violence against women. Turk J Psychiatry. 2012;23(2):1-7.

43. Özcan NK, Günaydın S, Çitil ET. Domestic violence against women in Turkey: a systematic review and meta analysis. Arch Psychiatr Nurs. 2016;30(5):620-9.

44. Puri M, Tamang J, Shah I. Suffering in silence: consequences of sexual violence within marriage among young women in Nepal. BMC Public Health. 2011;11(1):1-10.

45. Ragetlie R, Sano Y, Antabe R, Luginaah I. Married women's experiences of intimate partner violence and utilization of antenatal health care in Togo. Sex Reprod Healthcare. 2020. https://doi.org/10.1016/j.srhc.2019.100482.

46. Rai R, Rai AK. Sexual violence and poor mental health of women: an exploratory study of Uttar Pradesh, India. Clin Epidemiol Global Health. 2019;8(1):194-8. https://doi.org/10.1016/j.cegh.2019.06.013.

47. Rao S. A natural disaster and intimate partner violence: Evidence over time. Soc Sci Med. 2020. https://doi.org/10.1016/j.socscimed.2020. 112804.

48. RapeStatistics. (2019). Rape Statistics By Country Population, https:// worldpopulationreview.com/country-rankings/rape-statistics-by-country, Accessed 18 Jan 2020

49. Rennison CM, Dragiewicz M, DeKeseredy WS. Context matters: Violence against women and reporting to police in rural, suburban and urban areas. Am J Crim Justice. 2013:38(1):141-59.

50. Sanz-Barbero B, Vives-Cases C, Otero-García L, Muntaner C, TorrubianoDomínguez J, O'Campo YP. Intimate partner violence among women in Spain: the impact of regional-level male unemployment and income inequality. Eur J Public Health. 2015;25(6):1105-11.

51. Schneider D, Harknett K, McLanahan S. Intimate partner violence in the great recession. Demography. 2016;53(2):471-505.

52. Siddique JA. Age, marital status, and risk of sexual victimization: similarities and differences across victim-offender relationships. J Interpers Violence. 2016;31(15):2556-75.

53. Stylianou AM. Economic abuse within intimate partner violence: a review of the literature. Violence Vict. 2018;33(1):3-22. 
54. Tarzia L. Toward an ecological understanding of intimate partner sexual violence. J Interpers Violence. 2020. https://doi.org/10.1177/0886260519 900298.

55. Watts C, Zimmerman C. Violence against women: global scope and magnitude. Lancet. 2002;359(9313):1232-7.

56. WHO. (2013). Global and regional estimates of violence against women: prevalence and health effects of intimate partner violence and nonpartner sexual violence. Geneva, Switzerland: World Health Organization, https://apps.who.int/iris/handle/10665/85239, Accessed 10 July 2020.

57. WHO. (2019). Respect Women: Preventing Violence against Women. Geneva, Switzerland: World Health Organization, https://www.who.int/reproducti vehealth/publications/preventing-vaw-framework-policymakers/en/, Accessed 12 June 2020.

58. Yüksel-Kaptanoğlu I, Türkyılmaz AS, Heise L. What puts women at risk of violence from their husbands? Findings from a large, nationally representative survey in Turkey. J Interpers Violence. 2012;27(14):2743-69.

\section{Publisher's Note}

Springer Nature remains neutral with regard to jurisdictional claims in published maps and institutional affiliations.
Ready to submit your research? Choose BMC and benefit from:

- fast, convenient online submission

- thorough peer review by experienced researchers in your field

- rapid publication on acceptance

- support for research data, including large and complex data types

- gold Open Access which fosters wider collaboration and increased citations

- maximum visibility for your research: over 100M website views per year

At BMC, research is always in progress.

Learn more biomedcentral.com/submissions 